\title{
Combining ability of tomato lines in saladette-type hybrids
}

\author{
Marcela Carvalho Andrade (1*); Alex Antônio da Silva ('); Thiago Vicenzi Conrado ('); \\ Wilson Roberto Maluf ( $\left.{ }^{2}\right)$; Thiago Matos Andrade ( $\left.{ }^{3}\right)$; Celso Mattes de Oliveira ( ${ }^{2}$ ) \\ (') Universidade Federal de Lavras (UFLA), Departamento de Biologia, Caixa Postal 3037, 37200-000 Lavras (MG), Brasil. \\ (2) UFLA, Departamento de Agricultura, 37200-000 Lavras (MG), Brasil. \\ (3) Universidade Federal de Sergipe (UFS), São Cristóvão (SE), Brasil. \\ $\left(^{*}\right)$ Corresponding author: marcellinhaufla@gmail.com
}

Received: Feb. 10, 2014; Accepted: June 9, 2014

\begin{abstract}
Given the growing importance of the saladette fresh tomato market in Brazil, the objective of this paper was to assess the combining abilities of lines potentially useful as parents of hybridsin this class. The experiment consisted of28 genotypes, 18 hybrids from a partial diallel crossobtained from crossing two groups of tomato lines (Group I, with 9 parents, and Group II, with 2 parents), 8 F 1 experimental hybrids, and 2 commercial checks. Traits evaluated were total yield, mean fruit mass, fruit shelf life, shape and percentsoluble solids. Additive genetic effects were generally more important than non-additive effects for all traits evaluated. The TOM-542 and TOM-734 lines, from group I, and the TOM-720 line, from group II, presented high general combining ability (GCA) estimates for most of the traits of importance for saladette tomatoes, and were therefore considered suitable parents of hybrids of this class. Higher fruit shelf life of TOM-723 as a parental line compared with TOM-720 (Group II), was mainly attributed to the presence in the former of the nor ${ }^{A}$ allele, which controls longer fruit shelf life. F1 hybrids (TOM-542 x TOM-720), (TOM-580 x TOM-720), (TOM-734 x TOM-720), and (TOM-727 x TOM-720) showed good performance and fruit quality and thus constitute possible commercial varieties.
\end{abstract}

Key words: Solanum lycopersicum, saladette tomatoes, partial diallel.

\section{Capacidade combinatória de linhagens de tomateiro em híbridos do tipo italiano}

\section{Resumo}

Devido à crescente importância do mercado do tomate tipo italiano no Brasil, objetivou-se conhecer a capacidade combinatória de linhagens de tomateiro potencialmente utilizáveis como genitoras de híbridos voltados a esse segmento. O experimento constituiu-se de 28 genótipos, sendo 18 híbridos oriundos de um dialelo parcial, obtido pelo cruzamento entre dois grupos de linhagens: Grupo I (nove genitores) e Grupo II (dois genitores), oito híbridos adicionais e duas testemunhas comerciais. Foram avaliados produção total, massa média de frutos, firmeza, formato e teor de sólidos solúveis. Houve predominância dos efeitos gênicos aditivos para todas as características avaliadas. As linhagens TOM-542 e TOM-734, pertencentes ao Grupo I, e TOM-720, Grupo II, apresentaram estimativas elevadas de capacidade geral de combinação para a maioria das características de importância para o segmento de tomate italiano, portanto, recomendadas para a obtenção de híbridos desse tipo. A superioridade da linhagem TOM-723 sobre a TOM-720 (Grupo II) quanto à firmeza de frutos foi atribuída, principalmente, à presença, na primeira, do alelo nor ${ }^{A}$, que condiciona maior conservação pós-colheita. Os híbridos experimentais F1 (TOM-542 x TOM-720), F1 (TOM-580 x TOM-720), F1 (TOM-734 x TOM-720) e F1 (TOM-727 x TOM-720) apresentaram bom desempenho agronômico e qualidade de fruto, constituindo possíveis materiais comerciais.

Palavras-chave: Solanum lycopersicum, tomate saladette, dialelo parcial.

\section{INTRODUCTION}

The tomato market is formed by two distinct supply chains, characterized either by the fresh market segment, with fruit intended for fresh consumption, or the processing tomato segment. Shape and size of the fruit define the varietal types for the fresh market segment, which comprise five main classes (Nascimento, 2011), which are based on fruit size, shape and/or number of locules: Santa Cruz (barrel shaped fruit), Salada (oblate to globe-shaped fruit with 4-5 locules), Caqui (large oblate fruit with >6 locules), Italian (also known as Saladette, elongated fruit with 2-3 locules) and Cherry (which included globe to grape-shaped fruit usually with $<2 \mathrm{~cm}$ diameter).

A study performed by ABCSEM (2010) showed that, out of 55,000 hectares yearly grown with tomatoes in Brazil, 
little over 38,000 hectares are intended for the fresh market segment, of which 19,000 hectares are in the Salad class, 11,000 hectares are Santa Cruz, and the remaining refers mostly to the two other classes, the Italian/saladette, with 8,000 hectares and Cherry with approximately 210 hectares.

Fruit appearance is a decisive factor for the marketing of tomato (Andreuccetti et al., 2005; Silva et al., 2013.). Andreuccetti et al. (2005) reported that the elongated fruit was preferred by consumers over rounded types. These authors also reported that an ideal tomato for consumption would be the one with red color, uniformity, firmness and without presence of injuries.

The dissatisfaction of the market with the quality of currently marketed tomatoes, along with the pursuit of a healthier diet, have made the consumers more aware of fruit quality and fostered the search for new types (Andreuccetti et al., 2005; Silva et al., 2013), favoring the growth of consumption of Italian tomatoes, which are often associated with better flavor. According to Giordano et al. (2003), cultivars belonging to this segment are characterized by having sweet fruit (good balance of sugar/acid ratio), pleasant texture and aroma, intense red color and uniform ripening of fruit. Cultivars of the Italian group have fruit with elongated shape (= fruit length/diameter ratio $>>1$ ) and usually high content of total soluble solids compared to the traditional table tomato (Nascimento, 2011). Given its inherent characteristics, hybrids of this group of tomatoes would be an alternative to meet consumer demands.

Tomato breeders have long been deploying hybrid cultivars in order to obtain higher proportion of fruit with commercial standard, better nutritional quality, resistance to multiple diseases and longer fruit shelf life. Ripening and color mutants are often used in hybrids to increase the firmness and postharvest life of tomato fruit. Mutant alleles that may act markedly on the postharvest shelf life of fruits are "alcobaça" (nor $\left.{ }^{\mathrm{A}}\right)$, "ripening inhibitor" (rin) and "non ripening” (nor) (Andrade Junior et al., 2005; Kim et al., 2013; Garg et al., 2014). The color mutant alleles "bigh pigment" $(h p)$ and "old gold crimson" $\left(o^{c}\right)$ are responsible for increasing the production of carotenoids, especially lycopene, in the fruit, improving the nutritional quality, and can be used together with ripening mutant alleles within the same genotype, allowing simultaneous improvements on both postharvest shelf life and nutritional quality of fruit (Andrade Junior et al., 2005; Cá et al., 2006).

In hybrid breeding programs, diallel analysis facilitates the understanding of the genetic effects involved in the control of the traits, and may indicate the best choice of parents and/or the most promising hybrid combinations (Ramalho et al., 1993).

The current study intended to estimate the combining abilities of tomato lines potentially useful as parents of saladette-type hybrids, in order to identify promising potential parents for new hybrids with superior fruit quality that are competitive with currently grown imported cultivars.

\section{MATERIAL AND METHODS}

The experiment was conducted from February to October 2011 in greenhouses located in the county of Ijaci, Minas Gerais State, Brazil. The genetic material tested consisted of 26 tomato hybrids, 18 of which were experimental hybrids obtained anew in a partial diallel scheme, eight were additional experimental hybrids, and two were controls (Giuliana-F1 and Tyna-F1, both Saladette cultivars with indeterminate growth habit from the company Sakata Sudamerica).

The partial diallel was obtained by crossing two groups of lines, named I and II (Table 1). Genotypes of the Group I comprised nine lines (female parents) of different types, labeled $1=$ TOM-542, $2=$ TOM-580, $3=$ TOM-692, $4=$ TOM-698, $5=$ TOM-732, $6=$ TOM-734, $7=$ TOM-743, $8=$ TOM-684 and $9=$ UQMS-685-green hypocotil. Group II consisted of two lines, both of the Italian type, representing the male parents, $1^{\prime}=$ TOM-720 and 2' $=$ TOM-723.

The additional hybrids were (TOM-650 x TOM-720), F1(NC-2Y x TOM-720), F1(NC-2Y x TOM-723), F1(TOM-727 x TOM-720), F1(TOM-719 x TOM-723), F1(TOM-718 x TOM-723), F1(TOM-720 x TOM-723) and F1(TOM-658 x BPX-381G-10-05-03-01BULK) (Table 2).

Similarly to the two commercial checks, all 26 experimental hybrids had indeterminate growth habit. They bear the disease resistances available in their respective parents (Tables 1 and 2), and, also depending on the parental combination (Tables 1 and 2), some may bear the allele alcobaça $\left(\right.$ nor $\left.^{\mathrm{A}}\right)$ (heterozygous when present) and/or the allele old goldcrimson $\left(o g^{c}\right)$ homozygous, heterozygous.

Seeds were sown in 128-cell styrofoam trays and, after 30 days, seedlings were transplanted to the field in a randomized block design with 28 treatments and 4 replications. Each plot consisted of a row with 14 plants, spaced $1.20 \mathrm{~m}$ between rows and $0.40 \mathrm{~m}$ between plants. Plants were individually staked with a single pole, and pruned to a single stem.

In the period from August $11^{\text {st }}$ to September $12^{\text {nd }}, 2011$, 9 harvests were performed. The evaluated traits were: total fruit yield: total mass of fruit harvested in each plot during the 9 harvests, expressed as t.ha ${ }^{-1}$;

average mass per fruit: obtained by dividing the total fresh mass of fruit harvested in each plot by their respective number of fruit throughout the harvest, expressed in g.fruit ${ }^{-1}$;

- postharvest shelf life: measured according to the nondestructive technique developed by Calbo and Calbo (1989) and Calbo and Nery (1995). The measurements were initiated one day after harvesting the fruits at the breaker stage (day 1) and continuously performed every 
Table 1. Description of the parents of partial diallel hybrids

\begin{tabular}{|c|c|}
\hline Lines of the Group I & Description \\
\hline $1=\mathrm{TOM}-542$ & $\begin{array}{l}\text { Determinate growth habit. Saladette type fruit (Rio Fuego). Resistance to Ve, I, } I_{2} \text {. Homozygous for the } \\
\text { alleles } 0 g^{c} \text { and } h p \text {. }\end{array}$ \\
\hline $2=T O M-580$ & Determinate growth habit. Saladette type fruit (Rio Grande). Resistance to Ve, I, I, Mi and Pto. \\
\hline $3=\mathrm{TOM}-692$ & Determinate growth habit. Saladette type fruit. Resistance to Sw-5, Ty-1, Ve (?), I (?) and I \\
\hline $4=\mathrm{TOM}-698$ & Determinate growth habit. Saladette type fruit. Resistance to Ty-1, Ve (?), I (?), I. \\
\hline $5=\mathrm{TOM}-732$ & Determinate growth habit. Saladette type fruit (Rio Fuego). Resistance to Ve, Sw-5, Mi and $\mathrm{I}_{2}$. \\
\hline $6=\mathrm{TOM}-734$ & Determinate growth habit. Saladette type fruit. Resistance to Ve, Sw- $5, \mathrm{I}_{2}$. \\
\hline $7=\mathrm{TOM}-743$ & $\begin{array}{l}\text { Determinate growth habit. Santa cruz type fruit. Resistance to Ve, I, Sw-5, } I_{2}(?), S m \text {. Homozygous for } \\
\text { the alleles ogc and } H P \text {. }\end{array}$ \\
\hline $8=$ TOM-684 & Indeterminate growth habit. Santa cruz type fruit. Resistance to Ve, I, Sm, Mi, Sw-5 and Pto. \\
\hline 9 = UQMS-685-green hypocotyl & $\begin{array}{l}\text { Indeterminate growth habit. Santa cruz type fruit. Resistance to Ve, I, Sm, Mi, Sw- } 5 \text { and Pto. About } \\
25 \% \text { of the plants have green hypocotyl, a characteristic associated with male sterility conferred by the } \\
\text { allele ms- } 10 \text { in homozygosis. (Only the male-sterile plants were used to obtain the respective hybrids in } \\
\text { this study). }\end{array}$ \\
\hline Lines of the Group II & Description \\
\hline $1^{\prime}=\mathrm{TOM}-720$ & Italian-type line, indeterminate growth habit. \\
\hline $2^{\prime}=$ TOM-723 & Italian-type line, indeterminate growth habit. Homozygous for the alleles $\mathrm{og}^{\mathrm{C}}$ and nor. \\
\hline
\end{tabular}

Table 2. Description of the additional hybrids

\begin{tabular}{|c|c|}
\hline Hybrids & Description \\
\hline F1(TOM-650 x TOM-720) & Italian-type hybrid, indeterminate growth. Resistance to Ve, I, I. Heterozygous for the allele nor ${ }^{\mathrm{A}}$. \\
\hline F1(NC-2Y x TOM-720) & Saladinha-type hybrid, indeterminate growth. Resistance to $\mathrm{V}, \mathrm{I}, \mathrm{I}_{2}$. \\
\hline F1(NC-2Y x TOM-723) & Saladinha-type hybrid, indeterminate growth. Resistance to $\mathrm{V}, \mathrm{I}, \mathrm{I}_{2}$. Heterozygous for the allelesog ${ }^{\mathrm{c}}$ and nor ${ }^{\mathrm{A}}$. \\
\hline F1(TOM-727 x TOM-720) & Italian-type hybrid, indeterminate growth \\
\hline $\begin{array}{l}\text { F1(TOM-718 } \times \text { TOM-723) } \\
\text { F1(TOM-719 } \times \text { TOM-723) }\end{array}$ & Italian-type hybrid, indeterminate growth. Heterozygous for the alleles $o g^{c}$ and nor. \\
\hline F1(TOM-720 x TOM-723) & Italian-type hybrid, indeterminate growth. Heterozygous for the alleles $\mathrm{og}^{\mathrm{c}}$ and nor ${ }^{\mathrm{A}}$. \\
\hline $\begin{array}{l}\text { F1(TOM-658 x BPX-381G- } \\
-10-05-03-01 \text { BULK) }\end{array}$ & $\begin{array}{l}\text { Santa Cruz-type hybrid, indeterminate growth. Resistance to Ve, I, } \mathrm{I}_{2}, \mathrm{Mi}, \mathrm{Sw}-5, \mathrm{Sm}(?) \text {. Homozygous for the } \\
\text { allele og }{ }^{c} \text { and heterozygous for } \mathrm{hp} \text {. }\end{array}$ \\
\hline
\end{tabular}

two days, until day 21 after the breaker, with evaluation of 4 fruits per plot. The results were expressed as numbers of days for fruit to attain firmness equivalent to $2 \times 10^{4}$ $\mathrm{Nm}^{-2}$;

- fruit shape (Lengh/Diameter ratio): obtained by dividing the length (L) by the diameter (D) of the fruit $(\mathrm{L} / \mathrm{D}$ ratio), in a sample of 10 fruits per plot;

- soluble solids content in fruits: determined by direct reading of Brix in a refractometer, expressed as a plot average of 4 fruit sampled per plot.

Analyses of variance and F-tests were run for each of the traits, in accordance to a randomized block design. Mean comparison was performed through the Scott-Knott test. Data were analyzed using the statistical software R ( R Core Team, 2013).

In the partial diallel analysis, which included only 18 hybrids obtained from crossing the lines of group I with group II, we obtained the mean squares and estimates of general (GCA) and specific (SCA) combining ability in each evaluated trait. For this purpose, we used the method 4 of Griffing (1956) adapted for partial diallel (Cruz et al., 2004), with the statistical model: $Y_{i j}=\mu+g_{i}+g_{j}+s_{i j}+e_{i j}$, where $Y_{i j}$ is the observation of hybrid combination of the $\mathrm{i}$-th parent of the group I and the $\mathrm{j}$-th parent of the group II; $\mu$ is the overall mean; $g_{i}$ is the general combining ability of the $\mathrm{i}$-th parent of the group $\mathrm{I}$; $\mathrm{g}_{\mathrm{j}}$ is the general combining ability of the $j$-th parent of the group II; $s_{i j}$ is the specific combining ability between $i$ and $j$ parents of the groups I and II; $e_{i j}$ is the experimental error.

The diallel analysis was performed in the Genes software (Cruz, 2001) and the following constraints were adopted to obtain the estimates (Cruz et al., 2004):

$\sum \mathrm{g}_{\mathrm{i}}=0(\mathrm{i}=1,2, \ldots, \mathrm{p}) ; \sum \mathrm{g}_{\mathrm{j}}=0(\mathrm{j}=1,2, \ldots, \mathrm{q}) ; \sum \mathrm{s}_{\mathrm{ij}}=0$

In order to verify the contribution of additive effects (general combining ability - GCA) and non-additive effects (specific combining ability - SCA), we calculated the coefficient of determination $\left(\mathrm{R}^{2}\right)$ through the ratio of 
the sum of squares of the additive effects (GCA) and nonadditive effects (SCA) and the sum of squares of treatments for each trait studied (Ramalho et al., 1993).

\section{RESULTS AND DISCUSSION}

\section{Diallel analysis}

The mean squares of treatments showed significant differences among the genotypes included in the partial diallel cross, for all traits analyzed (F-test, $\mathrm{p}<0.01$ ) (Table 3). The estimates of GCA for parents of the Group II were significant $(\mathrm{p}<0.01)$ for all traits measured, indicating that the lines TOM-720 and TOM-723 are quite divergent as to those traits and that additive genetic effects are important in their expression (Table 3). The lines in Group I are less divergent from each other than the Group II for total yield, average mass per fruit and shelf life, which is evidenced by non-significant estimates of GCA of these traits. The SCA, and therefore the non-additive genetic effects, were significant $(\mathrm{p}<0.01)$ for total yield, average fruit mass and fruit shape, but were not significant for the shelf life and soluble solids (Table 3).

In group I, the estimates of GCA effects for total yield and average fruit masswere highest for lines 1 (TOM-542), 2 (TOM-580) and 8 (TOM-684) (Table 4). However, the amplitudes of variations in GCA estimates in the Group I were small (respectively6.167 $\mathrm{t} \mathrm{ha}^{-1}$ and $7.518 \mathrm{~g}_{\text {fruit }}{ }^{-1}$ ) compared with GCA amplitudes of the group II $\left(14.074 \mathrm{t} \mathrm{ha}^{-1}\right.$ and $11.164 \mathrm{~g}$ fruit $\left.^{-1}\right)$. Therefore, selection of parents for higher yield and greater average mass should be done preferably within Group II. Line 1'(TOM-720) of the Group II showed positive values of $g_{j}$ for total yield and average fruit mass, which indicates a favorable increase of these traits in crosses in which it participates, relative to the other parent 2' (TOM-723), although it tends to cause a decrease in fruit shelf life. Non-additive effects are indicated by SCA estimates and are also important in the expression of total yield and average fruit mass of hybrids. The amplitudes of variation were $11.544 \mathrm{t} \mathrm{ha}^{-1}$ and $19.026 \mathrm{~g} \mathrm{fruit}^{-1}$, respectively (Table 5), comparable to those found for GCA of the Group II. Pádua (2010), in evaluations of tomato lines with determinate growth, and Maciel (2010) found that additive effects were predominant for the total yield and average fruit mass.

Significant differences in shelf life were detected across the GCA of lines from Group II only (Table 4). In this group, the amplitude of variation of GCA was 3.438, while in the Group I, the amplitude was 2.668. This may be accounted for the fact that 2'(TOM-723), in contrast to the 1' (TOM-720), has the ripening mutant gene alcobaça $\left(n o r^{\mathrm{A}}\right)$, which imparts longer shelf life to its heterozygous hybrids (Andrade Junior et al., 2005; Cá et al., 2006).No significant differences were detected for SCA, indicating that additive effects (GCA) are more important to obtain fruit with longer shelf life in the set of hybrids in question. Major differences in postharvest shelf lifewere mainly determined by the activity of the allele nor ${ }^{\mathrm{A}}$ present in the strain 2'(TOM-723).It is worth noting, however, that the methodology used to determine the firmness, developed by Calbo and Calbo (1989) and Calbo and Nery (1995), may not have been entirely appropriate for tomatoes with elongated shape, because during the measurements, we observed that the elongated fruit shape may have influenced the formation of ellipses on the compression surface, depending on the support given to the outer wall of the fruit by the walls of locales'. Thus, the method itself may have caused an increase in experimental error, masking the results, making it difficult to determine differences existing between genotypes not carrying $n o r^{\mathrm{A}}$.

Table 3. Summary of the diallel analysis for total yield, average mass per fruit, fruit shelf life, shape and soluble solids content in fruits of tomato genotypes. Lavras, Minas Gerais State, UFLA, 2012

\begin{tabular}{|c|c|c|c|c|c|}
\hline \multirow[b]{2}{*}{ Source of variation } & \multicolumn{5}{|c|}{ Mean squares } \\
\hline & Total yield $\left(\mathrm{t} . \mathrm{ha}^{-1}\right)$ & $\begin{array}{l}\text { Average mass per } \\
\text { fruit (g.fruit }{ }^{-1} \text { ) }\end{array}$ & $\begin{array}{c}\text { Shelf life } \\
\text { (number of days) }\end{array}$ & $\begin{array}{l}\text { Shape } \\
\text { (L/D ratio) }\end{array}$ & $\begin{array}{l}\text { Soluble solids } \\
\text { ('Brix) }\end{array}$ \\
\hline Treatments (17 DF) & $268.874^{* *}$ & $281.901^{* *}$ & $72.630^{* *}$ & $1.238^{* *}$ & $1.477^{* *}$ \\
\hline GCAGroup I (8 DF) & $35.369^{\text {ns }}$ & $61.031^{\text {ns }}$ & $26.091^{\mathrm{ns}}$ & $2.293^{* *}$ & $1.079^{* *}$ \\
\hline GCAGroup II (1 DF) & $3564.938^{* *}$ & $2243.720^{* *}$ & $850.539^{* *}$ & $1.136^{* *}$ & $12.458^{* *}$ \\
\hline SCA (8 DF) & $90.372^{* *}$ & $257.545^{* *}$ & $21.931^{\mathrm{ns}}$ & $0.196^{* *}$ & $0.502^{\text {ns }}$ \\
\hline Residual & 17.522 & 55.217 & 13.716 & 0.033 & 0.310 \\
\hline DF residual & 51 & 51 & 50 & 51 & 51 \\
\hline $\mathrm{R}^{2}(\%) \mathrm{GCA}$ & 84.18 & 57.00 & 85.80 & 92.55 & 84.00 \\
\hline $\mathrm{R}^{2}(\%) \mathrm{SCA}$ & 15.82 & 43.00 & 14.20 & 7.45 & 16.00 \\
\hline Mean $(\mu)$ & 41.913 & 102.209 & 19.041 & 1.512 & 4.764 \\
\hline SDM & 0.4933 & 0.8757 & 0.2182 & 0.0068 & 0.0328 \\
\hline
\end{tabular}

ability; SCA: specific combining ability; DF Residual: degrees of freedom of the residual; SDM: standard deviation of the mean; $\mathrm{R}^{2}$ : coefficient of determination. 
There were significant effects within groups I and II for GCA and SCA on fruit L/D ratio, indicating that both the additive and non-additive effects are responsible for the expression of fruit shape; similar results were obtained by Pádua (2010). The coefficient of determination indicated a predominance of additive effects (Table 3). Indeed, while the GCA within the Group 1 (Table 4) ranged from -0.239 to
+0.306 (amplitude of 0.545 ), the SCA ranged from -0.069 to +0.069 , an amplitude of only 0.138 (Table 5 ).

Mean L/D ratio was 1.51 for shape, which characterizes the hybrids tested as elongated ( $\mathrm{L} / \mathrm{D}>1.5)$, and classifies them into the Italian/Saladette class (Table 3). In GCA estimates, lines 1 (TOM-542), 3 (TOM-692) and 6 (TOM-734) showed higher estimates of $\mathrm{g}_{\mathrm{i}}$, which indicates an increase

Table 4. Estimates of the general combining abilities $\left(\hat{\mathrm{g}}_{\mathrm{i}}\right.$ and $\left.\hat{\mathrm{g}}_{\mathrm{j}}\right)$ for total yield, average mass per fruit, fruit shelf life, shape and soluble solids content in fruits of tomato genotypes and standard deviations (SD) of effects of parents. Lavras, Minas Gerais State, UFLA, 2012

\begin{tabular}{|c|c|c|c|c|c|c|}
\hline & Lines & $\begin{array}{l}\text { Total yield } \\
\text { (t.ha-1) }\end{array}$ & $\begin{array}{l}\text { Average mass } \\
\text { per fruit } \\
\left(\text { g.fruit }{ }^{-1}\right)\end{array}$ & $\begin{array}{c}\text { Shelf life } \\
\text { (number of days } \\
\text { to } 2 \times 10^{4} \mathrm{~N} / \mathrm{m} 2 \text { ) }\end{array}$ & $\begin{array}{l}\text { Shape } \\
\text { (L/D ratio) }\end{array}$ & $\begin{array}{l}\text { Soluble solids } \\
\text { ( }{ }^{\circ} \text { Brix) }\end{array}$ \\
\hline \multirow{9}{*}{$\begin{array}{l}\text { Group I } \\
\left(\hat{\mathbf{g}}_{\mathrm{i}}\right)\end{array}$} & 1 TOM-542 & 1.109 & 0.783 & 0.747 & 0.131 & 0.046 \\
\hline & 2 TOM-580 & 2.361 & 4.189 & -0.904 & 0.025 & -0.095 \\
\hline & 3 TOM-692 & 0.095 & -3.220 & 0.452 & 0.059 & -0.285 \\
\hline & 4 TOM-698 & 1.767 & -0.469 & -0.850 & -0.092 & -0.017 \\
\hline & 5 TOM-732 & -2.286 & -2.042 & -1.415 & 0.013 & 0.183 \\
\hline & 6 TOM-734 & -3.806 & -3.329 & 1.253 & 0.306 & 0.315 \\
\hline & 7 TOM-743 & -0.981 & -1.370 & -0.265 & 0.016 & 0.092 \\
\hline & 8 TOM-684 & 2.146 & 2.369 & 0.706 & -0.239 & -0.060 \\
\hline & $\begin{array}{l}9 \text { UQMS-685- } \\
\text { green hypocotyl }\end{array}$ & -0.405 & 3.089 & 0.276 & -0.219 & -0.179 \\
\hline SD $\left(\hat{\mathbf{g}}_{i}\right)$ & & 1.3953 & 2.4769 & 0.6173 & 0.0192 & 0.0929 \\
\hline$S D\left(\hat{\mathbf{g}}_{i}-\hat{\mathbf{g}}_{i}^{\prime}\right)$ & & 2.0929 & 3.7154 & 0.9259 & 0.0288 & 0.1393 \\
\hline \multirow[t]{2}{*}{ Group II ( $\left.\hat{\mathbf{g}}_{j}\right)$} & 1'TOM-720 & 7.037 & 5.582 & -1.719 & 0.040 & 0.208 \\
\hline & 2' TOM-723 & -7.037 & -5.582 & 1.719 & -0.040 & -0.208 \\
\hline SD $\left(\hat{\mathbf{g}}_{j}\right)$ & & 0.4933 & 0.8757 & 0.2182 & 0.0068 & 0.0328 \\
\hline SD $\left(\hat{\mathbf{g}}_{j}-\hat{\mathbf{g}}_{j}^{\prime}\right)$ & & 0.9866 & 1.7515 & 0.4365 & 0.0136 & 0.0657 \\
\hline
\end{tabular}

SD: Standard deviation; ratio $\mathrm{L} / \mathrm{D}$, in which $\mathrm{L}$ and $\mathrm{D}$ are length and diameter of the fruit, respectively.

Table 5. Estimates of the specific combining abilities $\left(\hat{\mathrm{S}}_{\mathrm{ij}}\right)$ for total yield, average massper fruit, fruit shelf life, shape and soluble solids content in fruits of tomato genotypes. Lavras, Minas Gerais State, UFLA, 2012

\begin{tabular}{|c|c|c|c|c|c|}
\hline$\hat{s}_{i j}$ & Total yield $\left(\right.$ t.ha $\left.^{-1}\right)$ & $\begin{array}{l}\text { Average mass per } \\
\text { fruit (g.fruit }{ }^{-1} \text { ) }\end{array}$ & $\begin{array}{c}\text { Shelf life } \\
\text { (number of days) }\end{array}$ & $\begin{array}{l}\text { Shape } \\
\text { (L/D ratio) }\end{array}$ & $\begin{array}{c}\text { Soluble solids } \\
\left.\text { ( }{ }^{\circ} \text { Brix }\right)\end{array}$ \\
\hline $1 \times 1^{\prime}$ & -0.487 & -3.228 & 0.786 & 0.032 & -0.005 \\
\hline $2 \times 1^{\prime}$ & 2.812 & 2.743 & 0.314 & 0.057 & 0.005 \\
\hline $3 \times 1^{\prime}$ & -5.596 & -6.352 & 0.887 & -0.069 & 0.145 \\
\hline $4 \times 1^{\prime}$ & -2.490 & -9.117 & 0.299 & -0.045 & -0.161 \\
\hline $5 \times 1^{\prime}$ & -2.022 & -1.350 & -0.468 & -0.062 & -0.024 \\
\hline $6 \times 1^{\prime}$ & -0.737 & 9.513 & 0.851 & 0.030 & -0.217 \\
\hline $7 \times 1^{\prime}$ & 0.153 & 1.229 & -1.506 & 0.052 & 0.086 \\
\hline $8 \times 1^{\prime}$ & 2.596 & 2.652 & -0.535 & 0.027 & 0.020 \\
\hline $9 \times 11^{\prime}$ & 5.772 & 3.909 & -0.629 & -0.021 & 0.151 \\
\hline $1 \times 2^{\prime}$ & 0.487 & 3.228 & -0.786 & -0.032 & 0.005 \\
\hline $2 \times 2^{\prime}$ & -2.812 & -2.743 & -0.314 & -0.057 & -0.005 \\
\hline $3 \times 2^{\prime}$ & 5.596 & 6.352 & -0.887 & 0.069 & -0.145 \\
\hline $4 \times 2^{\prime}$ & 2.490 & 9.117 & -0.299 & 0.045 & 0.161 \\
\hline $5 \times 2^{\prime}$ & 2.022 & 1.350 & 0.468 & 0.062 & 0.024 \\
\hline $6 \times 2^{\prime}$ & 0.737 & -9.513 & -0.851 & -0.030 & 0.217 \\
\hline $7 \times 2^{\prime}$ & -0.153 & -1.229 & 1.506 & -0.052 & -0.086 \\
\hline $8 \times 2^{\prime}$ & -2.596 & -2.652 & 0.535 & -0.027 & -0.020 \\
\hline $9 \times 2^{\prime}$ & -5.772 & -3.909 & 0.629 & 0.021 & -0.151 \\
\hline
\end{tabular}

Lines: 1=TOM-542, 2=TOM-580, 3=TOM-692, 4=TOM-698, 5=TOM-732, 6=TOM-734, 7=TOM-743, 8=TOM-684, 9=UQMS-685-green hypocotyl, 1' = TOM-720 and 2 ' = TOM-723; ratio $\mathrm{L} / \mathrm{D}$, in which $\mathrm{L}$ and $\mathrm{D}$ are length and diameter of the fruit, respectively. 
of the $\mathrm{L} / \mathrm{D}$ ratio of fruit in their hybrids, and makes them particularly interesting for use as parents of Italian type hybrids (Table 4). The lines 4 (TOM-698), 8 (TOM-684) and 9 (UQMS-685-green hypocotyl) showed negative values of $\hat{g}_{i}$, which means that they contribute to reduce the L/D ratio. In the Group II, the TOM-720 line exhibited the highest GCA and is more appropriate than the TOM-723 line, for use as parent of hybrids of the Italian type.

In relation to soluble solids content, there were significant differences for GCA, between parents within both Group I and Group II. In Group I, the amplitude of variation between the GCA was 0.600 Brix, while in the Group II the range was $0.416^{\circ}$ Brix (Table 4). No significant differences were found for SCA (Table 3), suggesting no significant influence of non-additive effects in the determination of this trait. In contrast, in a study developed with tomato cultivars, Amaral Junior et al. (1999) observed that dominance effects were more important than additive effects for soluble solids content.

Soluble solids in lines 1 (TOM-542), 5 (TOM-732), 6 (TOM-734) and 7 (TOM-743) of the Group I showed positive values for estimates of $\mathrm{g}_{\mathrm{i}}$ (Table 4). In the Group II, line 1'(TOM-720) favors the increase in soluble solids content in all crosses in which it participated, in contrast with line 2' (TOM-723).

Line 1' (TOM-720) in Group II, stood out for its positive estimates of $\mathrm{g}_{\mathrm{i}}$ for total yield, average fruit mass, shape and soluble solids content, which makes it a potentially useful parent in obtaining Italian-type hybrids (Table 4). Its inferiority relative to 2' (TOM-723), regarding the shelf life, may be corrected in the future through introgression, in TOM-720, of the allelle nor ${ }^{A}$ conferring longer postharvest shelf life. In Group I, line 1 (TOM-542) had positive estimates of $g_{i}$ for all traits, and line 6 (TOM-734) showed the highest estimates for $\mathrm{L} / \mathrm{D}$ ratio and soluble solids. These are important features to be considered when obtaining Italian-type hybrids.

The hybrid combinations $9 \times 1$ ' [F1(UQMS-685green hypocotyl $\times$ TOM-720)], $3 \times$ 2' [F1(TOM-692 x TOM-723)], $2 \times 1$ ' [F1(TOM-580 x TOM-720)] and $8 \times$ 1' [F1(TOM-684 x TOM-720)] showed higher $\mathrm{s}_{\mathrm{ij}}$ estimates (Table 5) for yield. In addition, hybrids $2 \times 1$ ' and $8 \times 1$ ' also presented positive estimates for both $\mathrm{g}_{\mathrm{i}}$ and $\mathrm{g}_{\mathrm{j}}$.

The highest SCA estimates for average fruit mass were found in hybrid combinations in $6 \times 1$ 1' [F1(TOM-734 $\mathrm{x}$ TOM-720)], 4 × 2' [F1(TOM-698 x TOM-723)], $3 \times 2$ ' [F1(TOM-692 x TOM-723)] and 9 x 1' [F1(UQMS-685hip-verde $\mathrm{x}$ TOM-720)].

The major effects of $s_{\mathrm{ij}}$ for fruit shape were presented by hybrids $3 \times 2$ ' [F1(TOM-692 x TOM-723)], 5 × 2' [F1(TOM-732 x TOM-720)], $2 \times 1$ ' [F1(TOM-580 x TOM-720)] and $7 \times 1$ ' [F1(TOM-743 x TOM-720)]. All these combinations have a parent with positive GCA.
The hybrid combination 9 x 1' [F1(UQMS-685-green hypocotyl x TOM-720)] associates higher estimates of $s_{\mathrm{ij}}$ for total yield and average fruit mass and corresponds to the hybrid with the highest mean for these traits, with values of $54.32 \mathrm{t} \mathrm{ha}^{-1}$ and $114.79 \mathrm{~g}_{\text {fruit }}{ }^{-1}$, respectively (Table 7). It also showed positive estimate of $s_{\mathrm{ij}}$ for soluble solids, which was not, however, significantly different from those of other hybrids.

The hybrid combination $6 \times 1$ ' presented the highest content of soluble solids and L/D ratio, with 5.15 Brix and 1.89 respectively (Table 7 ), being the result of the combination between the lines TOM-734 and TOM-720, which had higher estimates of GCA for both traits (Table 4). Due to the predominance of additive effects on these traits, superior lines may be obtained from this combination via breeding and selection, in order to obtain further genetic progress in $\mathrm{L} / \mathrm{D}$ ratio and soluble solids.

The variations between the GCA were higher within the Group II than in Group I for all the traits studied, except fruit shape. Line TOM-720 of Group II showed the highest GCA for all the traits studied, except shelf life, and within the Group I, the line 1 (TOM-542) showed favorable general combining abilities for all traits analyzed, while the line 6 (TOM-734) stood out for its general combining ability favorable for shelf life, shape and soluble solids content, traits of remarkable importance for Italian tomatoes.

\section{Agronomic evaluation}

In addition to being potentially promising for continuation of breeding programs, lines when combined should be able to generate hybrids with higher or similar agronomic performance compared with existing commercial materials. The hybrids differ significantly from each other $(\mathrm{p}<0.01)$ for all agronomic variables (Table 6).

The total yield ranged from $63.65 \mathrm{t} \mathrm{ha}^{-1}$ for the control Tyna, to $28.45 \mathrm{t} \mathrm{ha}^{-1}$ for the hybrid F1 (TOM-718 x TOM-723). Diallel F1 hybrids (UQMS-685-green hypocotyl x TOM-720), F1(TOM-580 x TOM-720) and F1(TOM-684 $x$ TOM-720) from the cross with the line TOM-720, which showed positive GCA for total yield (Table 4) were those with higher yield values, not differing from the control Giuliana (Table 7).

Yield is an important trait, but when considering Italian tomatoes, yield alone is not enough. Visual and organoleptic characteristics should also be considered, such as the shape, size and flavor of fruit.

The F1 hybrids (NC-2Y x TOM-720), F1(NC-2Y x TOM-723) and the control Giuliana showed fruit with the highest average mass (Table 7). Diallel F1 hybrids (UQMS-685-green hypocotyl x TOM-720), F1(TOM-580 x TOM-720), F1(TOM-734 x TOM-720), F1(TOM-684 $\mathrm{x}$ TOM-720) and the additional F1 hybrid (TOM-727 x TOM-720) showed satisfactory values of average fruit mass, 
significantly higher than the controls Tyna and lower than the control Giuliana and F1 hybrids (NC-2Y x TOM-720) and F1(NC-2Y x TOM-723). Most promising diallel hybrids for this trait have the line TOM-720 as a parent, which has high GCA for average fruit mass.

In general, hybrids exhibited a good postharvest shelf life ranging from 22 days in the F1 hybrid (TOM-684 $\mathrm{x}$ TOM-723) to 14.95 days in the F1 hybrid (NC-2Y x TOM-720). Diallel hybrids and additional hybrids, with shelf life in the range of 22 days to 18.66 days, did not differ significantly from each other, and the controls are within this range (Table 7). In general, the hybrids with greater shelf life have the line TOM-723 as a parent, which carries the ripening mutant gene alcobaça $\left(\right.$ nor $\left.^{\mathrm{A}}\right)$, which promotes

Table 6. Summary of analysis of variance for total production, average mass per fruit, fruit shelf life, fruit shape and soluble solids of 28 tomato genotypes. Lavras, Minas Gerais State, UFLA, 2012

\begin{tabular}{|c|c|c|c|c|c|}
\hline \multirow[b]{2}{*}{ Source of variation } & \multicolumn{5}{|c|}{ Mean squares } \\
\hline & Total yield $\left(\right.$ t.ha $\left.^{-1}\right)$ & $\begin{array}{l}\text { Average mass per } \\
\text { fruit (g.fruit }^{-1} \text { ) }\end{array}$ & $\begin{array}{c}\text { Shelf life } \\
\text { (number of days) }\end{array}$ & $\begin{array}{l}\text { Shape } \\
\text { (L/D ratio) }\end{array}$ & $\begin{array}{l}\text { Soluble solids } \\
\text { ('Brix) }\end{array}$ \\
\hline Treatments (27 DF) & $352.371^{* *}$ & $811.605^{* *}$ & $18.363^{* *}$ & $0.174^{* *}$ & $0.364^{* *}$ \\
\hline Block (3 DF) & $23.039^{\text {ns }}$ & $685.30634^{* *}$ & $1.569^{\text {ns }}$ & $0.0049^{\text {ns }}$ & $0.083^{\text {ns }}$ \\
\hline Residual & 19.118 & 70.305 & 2.950 & 0.0036 & 0.078 \\
\hline DF Residual & 81 & 81 & 80 & 81 & 81 \\
\hline Mean & 42.17 & 104.08 & 19.20 & 1.50 & 4.75 \\
\hline CV(\%) & 10.37 & 8.05 & 8.95 & 4.01 & 5.90 \\
\hline
\end{tabular}

ns, ${ }^{* *}$ : significant and significant at 0.01 , respectively, by F-test; DF: Degrees of freedom; ratio L/D, in which L and D are length and diameter of the fruit, respectively; CV (\%): coefficient of variation.

Table 7. Estimates of the mean values of traits for total yield, average mass per fruit, fruit shelf life, shape and soluble solids content of 28 tomato genotypes. Lavras, Minas Gerais State, UFLA, 2012

\begin{tabular}{|c|c|c|c|c|c|}
\hline Treatment & $\begin{array}{l}\text { Total yield } \\
\left(\text { (t.ha }^{-1}\right)\end{array}$ & $\begin{array}{l}\text { Average mass } \\
\text { per fruit } \\
\text { (g.fruit }^{-1} \text { ) }\end{array}$ & $\begin{array}{c}\text { Shelf life } \\
\text { (number of } \\
\text { days) }\end{array}$ & $\begin{array}{l}\text { Shape } \\
\text { (L/D ratio) }\end{array}$ & $\begin{array}{c}\text { Soluble solids } \\
\text { ('Brix) }\end{array}$ \\
\hline $1 \times 11^{\prime}=\mathrm{F} 1(\mathrm{TOM}-542 \times \mathrm{TOM}-720)$ & $49.583 \mathrm{c}$ & $105.348 \mathrm{c}$ & $18.855 \mathrm{a}$ & $1.714 b$ & $5.013 \mathrm{a}$ \\
\hline $2 \times 1^{\prime}=\mathrm{F} 1(\mathrm{TOM}-580 \times \mathrm{TOM}-720)$ & $54.133 b$ & $114.723 b$ & $16.732 b$ & $1.633 c$ & $4.881 \mathrm{a}$ \\
\hline $3 \times 11^{\prime}=\mathrm{F} 1(\mathrm{TOM}-692 \times \mathrm{TOM}-720)$ & $43.453 c$ & $98.220 c$ & $18.661 \mathrm{a}$ & $1.542 \mathrm{~d}$ & $4.793 \mathrm{a}$ \\
\hline $4 \times 1^{\prime}=\mathrm{F} 1(\mathrm{TOM}-698 \times \mathrm{TOM}-720)$ & $48.233 c$ & 98.206 c & $16.771 \mathrm{~b}$ & $1.415 \mathrm{e}$ & $5.131 \mathrm{a}$ \\
\hline $5 \times 11^{\prime}=\mathrm{F} 1(\mathrm{TOM}-732 \times \mathrm{TOM}-720)$ & $44.651 \mathrm{c}$ & $104.399 \mathrm{c}$ & $15.123 b$ & $1.506 \mathrm{e}$ & $5.068 \mathrm{a}$ \\
\hline $6 \times 1^{\prime}=\mathrm{F} 1(\mathrm{TOM}-734 \times \mathrm{TOM}-720)$ & $44.414 \mathrm{c}$ & $113.976 b$ & 19.426 a & $1.888 \mathrm{a}$ & $5.150 \mathrm{a}$ \\
\hline $7 \times 11^{\prime}=\mathrm{F} 1(\mathrm{TOM}-743 \times \mathrm{TOM}-720)$ & $48.128 \mathrm{c}$ & $107.651 \mathrm{c}$ & $15.552 b$ & $1.620 \mathrm{c}$ & $4.931 \mathrm{a}$ \\
\hline $8 \times 1^{\prime}=\mathrm{F} 1($ TOM-684 $\times$ TOM-720) & $53.697 \mathrm{~b}$ & $112.813 b$ & $17.493 b$ & $1.340 \mathrm{f}$ & $4.831 \mathrm{a}$ \\
\hline 9x1' = F1(UQMS-685-green hypocotyl x TOM-720) & $54.329 b$ & $114.790 \mathrm{~b}$ & $16.969 \mathrm{~b}$ & $1.311 \mathrm{~g}$ & $4.943 \mathrm{a}$ \\
\hline $1 \times 2^{\prime}=\mathrm{F} 1(\mathrm{TOM}-542 \times \mathrm{TOM}-723)$ & $36.485 d$ & $100.637 c$ & 20.721 a & $1.571 \mathrm{~d}$ & $4.606 \mathrm{~b}$ \\
\hline $2 \times 2^{\prime}=\mathrm{F} 1(\mathrm{TOM}-580 \times \mathrm{TOM}-723)$ & $34.432 \mathrm{~d}$ & $98.073 \mathrm{c}$ & $19.541 \mathrm{a}$ & $1.440 \mathrm{e}$ & $4.456 \mathrm{~b}$ \\
\hline $3 \times 2^{\prime}=\mathrm{F} 1(\mathrm{TOM}-692 \times \mathrm{TOM}-723)$ & $40.570 \mathrm{~d}$ & $99.759 \mathrm{c}$ & 20.323 a & $1.601 \mathrm{c}$ & $4.700 \mathrm{~b}$ \\
\hline $4 \times 2^{\prime}=\mathrm{F} 1(\mathrm{TOM}-698 \times \mathrm{TOM}-723)$ & $39.140 \mathrm{~d}$ & $105.274 \mathrm{c}$ & 19.609 a & $1.425 \mathrm{e}$ & $4.762 \mathrm{a}$ \\
\hline $5 \times 2^{\prime}=\mathrm{F} 1(\mathrm{TOM}-732 \times \mathrm{TOM}-723)$ & $34.619 \mathrm{~d}$ & $95.935 \mathrm{c}$ & 19.569 a & $1.548 \mathrm{~d}$ & $5.087 \mathrm{a}$ \\
\hline $6 \times 2^{\prime}=$ F1(TOM-734 x TOM-723) & $31.819 \mathrm{e}$ & $83.785 \mathrm{~d}$ & $21.162 \mathrm{a}$ & $1.750 \mathrm{~b}$ & $4.562 \mathrm{~b}$ \\
\hline $7 \times 2{ }^{\prime}=\mathrm{F} 1(\mathrm{TOM}-743 \times \mathrm{TOM}-723)$ & $33.749 \mathrm{~d}$ & $94.029 \mathrm{~d}$ & $22.000 \mathrm{a}$ & $1.437 \mathrm{e}$ & $4.475 b$ \\
\hline $8 \times 2^{\prime}=\mathrm{F} 1(\mathrm{TOM}-684 \times \mathrm{TOM}-723)$ & $34.435 \mathrm{~d}$ & $96.344 \mathrm{c}$ & $22.000 \mathrm{a}$ & $1.207 \mathrm{~h}$ & $4.125 c$ \\
\hline 9x2' = F1(UQMS-685- green hypocotyl x TOM-723) & 28.704 e & $95.807 \mathrm{c}$ & 21.569 a & $1.274 \mathrm{~g}$ & $4.225 \mathrm{c}$ \\
\hline Giuliana-F1(control) & $57.932 b$ & $130.075 \mathrm{a}$ & $19.314 \mathrm{a}$ & $1.496 \mathrm{e}$ & $4.662 \mathrm{~b}$ \\
\hline Tyna-F1(control) & $63.653 \mathrm{a}$ & $108.767 \mathrm{c}$ & 20.647 a & $1.368 \mathrm{f}$ & $4.137 \mathrm{c}$ \\
\hline F1(TOM-650 x TOM-720) & $43.849 \mathrm{c}$ & $90.315 \mathrm{~d}$ & $19.470 \mathrm{a}$ & $1.343 \mathrm{f}$ & $4.975 \mathrm{a}$ \\
\hline F1(NC-2Y $\times$ TOM-720) & $44.992 \mathrm{c}$ & $139.437 \mathrm{a}$ & $14.954 \mathrm{~b}$ & $1.147 \mathrm{~h}$ & $4.944 \mathrm{a}$ \\
\hline F1(NC-2Y x TOM-723) & 30.386 e & $135.268 \mathrm{a}$ & $20.910 \mathrm{a}$ & $1.231 \mathrm{~h}$ & $4.312 \mathrm{c}$ \\
\hline F1(TOM-727 x TOM-720) & $47.506 \mathrm{c}$ & $113.776 \mathrm{~b}$ & $21.362 \mathrm{a}$ & $1.860 \mathrm{a}$ & $5.037 \mathrm{a}$ \\
\hline F1(TOM-719 x TOM-723) & $42.739 \mathrm{c}$ & $89.182 \mathrm{~d}$ & $20.031 \mathrm{a}$ & $1.682 \mathrm{c}$ & $4.644 \mathrm{~b}$ \\
\hline F1(TOM-718 $\times$ TOM-723) & 28.447 e & $80.182 \mathrm{~d}$ & $21.458 \mathrm{a}$ & $1.837 \mathrm{a}$ & $4.887 \mathrm{a}$ \\
\hline F1(TOM-720 x TOM-723) & $34.939 \mathrm{~d}$ & $91.449 \mathrm{~d}$ & 20.980 a & $1.726 b$ & $4.562 \mathrm{~b}$ \\
\hline F1(TOM-658 x BPX-381G-10-05-03-01BULK) & $31.903 \mathrm{e}$ & $96.289 \mathrm{c}$ & $16.405 b$ & $1.213 \mathrm{~h}$ & $5.019 \mathrm{a}$ \\
\hline Coefficient of variation & 10.367 & 8.055 & 8.948 & 4.012 & 5.901 \\
\hline
\end{tabular}

Means followed by the same letter in the column are not significantly different by Scott-Knott test at $5 \%$ significance; ratio L/D, in which L and D are length and diameter of the fruit, respectively. 
a longer postharvest preservation even when heterozygous, as noted by Andrade Junior et al., (2005) and Cá et al., (2006). Hybrids made with the parent TOM-723 are not significantly different from controls with regard to shelf life.

The diallel F1 hybrid (TOM-734 x TOM-720), the F1 (TOM-727 x TOM-720) and F1(TOM-718 x TOM-723) showed a higher L/D ratio, not different from each other (Table 7). Diallel F1 hybrids (TOM-734 x TOM-723) and F1(TOM-542 x TOM-720) and the F1 hybrid (TOM-720 $\mathrm{x}$ TOM-723) also showed high L/D ratio with $1.75,1.71$ and 1.73 , respectively. The $\mathrm{L} / \mathrm{D}$ ratio was 1.49 and 1.36 , for Giuliana and Tyna, being less than 1.5, so these controls may not be materials which may be strictly classified as Saladette or Italian, because they did show a pronounced elongated shape, the main trait that classifies tomatoes into this group. The control treatments are inferior to most of the evaluated experimental hybrids, mainly when compared with hybrids with the highest $\mathrm{L} / \mathrm{D}$ ratios.

Among the 28 hybrids evaluated, 16 had high content of soluble solids and did not differ from each other, and were superior to the controls Giuliana and Tyna (Table 7). The high Brix content for most of the evaluated experimental hybrids can be explained by the use of saladette parents with good levels of soluble solids, associated with the predominantly additive effects for this trait. The control Tyna was inferior to all available experimental hybrids, with the exception of the F1 hybrid (TOM-684 x TOM-723).

The hybrid from the diallel $\mathrm{F}_{1}$ (TOM-542 x TOM-720), F1(TOM-580 x TOM-720), F1(TOM-734 x TOM-720) and the F1 hybrid (TOM-727 x TOM-720) showed good performance for soluble solids, shape, shelf life, average fruit mass and satisfactory performance for total yield. The control Tyna had a higher total yield, but was inferior to these hybrids regarding the $\mathrm{L} / \mathrm{D}$ ratio and content of soluble solids, essential for Italian tomatoes. The same occurred to the control Giuliana, in spite of its total yield being similar to the F1 hybrid (TOM-580 x TOM-720).

\section{CONCLUSION}

Additive genetic effects predominated for the majority of the traits studied, which favors the breeding of superior lines through selection of genotypes in segregating populations from promising hybrid combinations.

The line TOM-720has the potential to be used as an elite line for the production of Italian hybrids, and can be improved for fruit shelf life through introgression of ripening mutant genes.

Experimental hybrids F1(TOM-734 x TOM-720), F1(TOM-542 x TOM-720), F1(TOM-580 x TOM-720) and F1(TOM-727 x TOM-720) show good agronomic performance, representing possible commercial materials.

\section{REFERENCES}

AMARAL JUNIOR, A.T.; CASALI, V.W.D.; CRUZ, C.D.; FINGER, F.L. Inferências genéticas na produçáo e qualidade de tomateiro sob cruzamento dialélico. Pesquisa Agropecuaria Brasileira, v.34, p.14071416, 1999. http://dx.doi.org/10.1590/S0100-204X1999000800013

ANDRADE JUNIOR, V.C.; MALUF, W.R.; FARIA, M.V.; BENITES, F.R.G.; SANTOS JÚNIOR, A.M. Yield and fruit quality of tomato hybrids heterozygous for ripening and color mutant alleles. Pesquisa Agropecuaria Brasileira, v.40, p.555-561, 2005.

ANDREUCCETTI, C.; FERREIRA, M.D.; TAVARES, M. Perfil dos compradores de tomate de mesa em supermercados da regiáo de Campinas. Horticultura Brasileira, v.23, p.148-153, 2005. http:// dx.doi.org/10.1590/S0102-05362005000100031

ASSOCIAÇÃO BRASILEIRA DO COMÉRCIO DE SEMENTES E MUDAS - ABCSEM. Tomate lidera crescimento e lucratividade no setor de hortaliças. Campinas, 2010. Disponível em: <http:// www.abcsem.com.br/noticia.php?cod=284>. Acesso: 16 jan. 2012.

CÁ, J.A.; MALUF, W.R.; GOMES, L.A.A.; NASCIMENTO, I.R.; FARIA, M.V.; LICURSI, V.; MORETTO, P. Long shelf life tomato hybrids with improved fruit color intensity. Pesquisa Agropecuaria Brasileira, v.41, p.1377-1384, 2006. http://dx.doi.org/10.1590/ S0100-204X2006000900005

CALBO, A.G.; CALBO, M.E. Medição e importância do potencial de parede. Revista Brasileira de Fisiologia Vegetal, v.1, p.41-45, 1989.

CALBO, A.G.; NERY, A.A. Medida de firmeza em hortaliças pela técnica de aplanação. Horticultura Brasileira, v.12, p.14-18, 1995.

CRUZ, C.D.; REGAZZI, A.J.; CARNEIRO, P.C.S. Modelos biométricos aplicados ao melhoramento genético. 3. ed. Viçosa: UFV, 2004. 480p.

CRUZ, C.D. Programa Genes: versão Windows. Aplicativo computacional em genética e estatística. Viçosa: UFV, 2001. 648p.

GARG, N.; CHEEMA, D.S.; CHAWLA, N. Manifestation of heterosis for fruit yield, quality and shelf-life in tomato (Solanum lycopersicum L.) hybrids incorporating rin, nor or alc alleles in main-and late-seasons of north Indian plains. Vegetable Science, v.40, p.28-33, 2014.

GIORDANO, L.B.; BOITEAUX, L.S.; CARRIJO, A.O.; MELO, P.C.T. Tomate San Vito: sabor na salada. Revista Cultivar Hortaliças e Frutas, v.22, p.26-28, 2003.

GRIFFING, B. Concep of general and specific combining ability in relation to diallel crosing systems. Australian Journal of Biological Science, v.9, p.463-493, 1956.

KIM, H-J.; LEE, H-R.; HYUN, J. Y.; HONG, D. O.; WON, D-C.; HARN, C. H. A SCAR Marker Linked to ripening-inhibitor in Tomato. Korean Journal of Breeding Science, v.45, p.104, 2013. http://dx.doi.org/10.9787/KJBS.2013.45.2.104

MACIEL, G.M.; MALUF, W.R.; SILVA, V.F.; GONÇALVES NETO, A.C.; NOGUEIRA, D.W.; GOMES, L.A.A. heterose e capacidade 
combinatória de linhagens de tomateiro ricas em acilaçúcares. Ciência e Agrotecnologia, v.34, p.1161-1167, 2010. http://dx.doi.org/10.1590/ S1413-70542010000500012

NASCIMENTO, I.R. Cresce a demanda por mini tomate italiano. Revista Campo \& Negócios HF, v.70, p.42-43, 2011.

PADUA, T.R.P.; GOMES, L.A.A.; MALUF, W.R.; CARVALHO FILHO, J.L.S.; GONÇALVES NETO, A.C.; ANDRADE, M.C. Capacidade combinatória de híbridos detomateiro de crescimento determinado, resistentes a Begomovirus e Tospovirus. Pesquisa Agropecuária Brasileira, v.45, p.818-825, 2010. http:// dx.doi.org/10.1590/S0100-204X2010000800007
RAMALHO, M.A.P.; SANTOS, J.B.; ZIMMERMANN, M.J.O. Genética quantitativa em plantas autógamas: aplicaçôes ao melhoramento do feijoeiro. Goiânia: UFG, 1993. 271p.

R FOUNDATION FOR STATISTICAL COMPUTING. R: a language and environment for statistical computing. Vienna, 2013. Disponível em: <http://www.R-project.org/>.

SILVA, R.T.D.; SOUZA NETA, M.L.D.; SOUZA, A.A.T.; OLIVEIRA, F.D.A.D.; OLIVEIRA, M.K.T.D.; PAMPLONA, J.D.P. Caracterização dos consumidores de tomate no município de Apodi-RN. Agropecuária Científica no Semiárido, v.9, p.104-109, 2013. 